'generally included in plant pathology in Europe', but, nevertheless, they wisely decide in the end to leave them with the entomologist. The opening chapter is a review of the nature, origin, and evolution of parasitism towards commensalism by specialization. Then follow two chapters on the reproduction of viruses, bacteria and fungi. The next six chapters are concerned with the nature of pathogenicity and cover the ability of the pathogen to breach the host by mechanical and chemical means, the importance of toxins, variability in the pathogen, and the inheritance of pathogenicity. 'There are also important contributions on spore germination and on soil pathogens in relation to the rhizosphere, but these are rather out of place and tond to break the continuity of the central theme.

About three-quarters of the text was prepared in more or less equal proportions by American and English authors. The other four contributions originated in Canada, India and New Zealand. There are comprehensive author and subject indexes and more than seventeen hundred literature references. It can be said now, without waiting for the third volume, that the editors and their advisory board have certainly achieved the task they set themselves in providing research workers and advanced students of applied biology with an exposition on plant pathology which is, in fact, unequalled in the English language.

\section{W. C. Moore}

\section{British Pharmaceutical Codex 1959}

Pp. xxix +1301 . (Jondon: The Pharmaceutical Press, 1959.) 70s.

"r THE British Pharmacopoia" is mainly used by pharmacists. "The British Pharmacoutical Codex" is of more interest to the doctor ; it tells him all he needs to know about the official drugs and their preparations, and adds a useful and authoritative summary of their actions and uses. It also gives spocifications for other drugs, both old and new. The new "Codex" contains seventy new genoral monographs mainly dealing with drugs introduced in the past five years, and about one hundred of the old general monographs have been deleted, so that the new edition is shorter than its predecessor, which was itself shorter than the 1949 edition. This shrinkage is due to the elimination of remedics no longer used. The leech was fully described in the 1954 edition with an account of its actions and uses, and recommendations for storage; that monograph has now been eliminated, and the "Codex" has become less picturesque than it was and more like "The British Pharmacopœia" ; the time will probably come when these two standard works will be amalgamated.

J. H. GADDUM

\section{Food Poisoning, Food-borne Infection and Intoxi- cation}

Nature, History, and Causation ; Measures for Prevention and Control. By Elliot B. Dewberry. Fourth edition. Pp. xvi $+411+40$ plates. (London: Leonard Hill (Books), Ltd., 1959.) 45s. net.

$\mathbf{T}$ is a platitude to say that everything we eat is 1 perishable, and it is therefore very difficult to understand why until relatively recently a large proportion of those entering the laboratories of the food industry were trained only in chemistry. Of these, some near enough to large industrial areas were able to attend classes in general bacteriology, a subject very difficult to tcach except to full-time students. 'The remainder were forced to obtain their knowledge solely from text-books. The establishment of courses in food technology at various technical colleges has eased the situation, but the facilities are not yet adequate for the requirements of a virile industry.

First produced in 1943 at a time when the industry was desperately short of laboratory staff, Dewberry's book was a most useful source of information to those dealing with war-time problems of food handling and processing. The third edition in 1950 was still produced "in complete conformity with the authorized economy standards". The present edition, expanded by some 100 pages to include chapters on food hygiene, canned foods and their inspection, and (briefly) $\mathrm{Cl}$. welchii food-poisoning, has changed little in quality of production. It has therefore become somewhat bulky for general use.

Although bacterial food-poisoning takes pride of place, sections are included on poisoning by metals, plants, fungi, fish and shellfish and on food allergy. For additional or confirmatory reading there are many references, making the book a most useful source of information for the food technologist and tho seriously minded executive. It is, in fact, good value for money.

F. H. BANFIELD

\section{Organic Reactions}

Vol. 10. Edited by Roger Adams, A. H. Blatt, V. Boekelheide, Arthur C. Cope, David Y. Curtin, Frank C. McGrew and Carl Niemann. Pp. vii +563 . (New York: John Wiley and Sons, Inc.; London : Chapman and Hall, Ltd., 1959.) 96s. net.

7 HIS volume contains a treatment in the usual detail of three reactions capable of wide application in organic chemistry. The first, dealt with by S. M. Parmerter, concerns the coupling of diazonium salts with aliphatic carbon atoms. An explanation of its character is followed by discussions of its mechanism, scope and limitations, and synthotic applications; the experimental conditions and procedures are then considered; and lastly there is a tabular survey, classified in twelvo sections, of the kinds of reactions in question. The treatment is limited to reactions in which the two nitrogen atoms of the diazonium salt remain in the new molecule.

The related Japp-Klingemann reaction is surveyed on similar lines by R. R. Phillips. The treatment of the third member of the triad, the celebrated Michael reaction, occupics the greater portion of the book (pp. 179-555) and affords a contribution of outstanding value: the thoroughness of this co-operative study by E. D. Bergmann, D. Ginsburg and R. Pappo, which was begun at the Weizmann Institute of Science, Rehovoth, is indicated by the accompanying list of 1,045 literature references.

At the end of this volume there are an author index and a chapter (subject) index covering Volumes $1-10$ of this invaluablo series. JOHN READ

Reports on the Progress of Applied Chemistry Vol. 42, 1957. Pp. 910. (London: Soeiety of Chemical Industry, 1958.) $100 \mathrm{~s}$.

7 H.IS very valuable reviow has grown appreciably in sizo and price. The separate articles aro all concisely written, and it would be difficult to say whore, if at all, any limitation could be attempted. Tho book will mostly be of interest to industrial 